\title{
ARTICLE
}

\section{H-point Standard Addition Method for the Simultaneous Spectrophotometric Determination of Captopril and Hydrochlorothiazide in Pharmaceutical Formulations}

\author{
Asmaa Ghanim Dawood ${ }^{a}$, Nagham Nadhim Habeeb ${ }^{b}$ and Lazeeza \\ Sattar Omer*c \\ ${ }^{a}$ Department of Pharmaceutical Chemistry, College of Pharmacy, Hawler Medical University, \\ Erbil, Iraq. \\ ${ }^{b}$ Department of Chemistry, College of Education, Mosul University, Mosul, Iraq. \\ ${ }^{c}$ Department of Pharmaceutical Chemistry, College of Pharmacy, Hawler Medical University, \\ Erbil, Iraq.
}

Received: $5^{\text {th }}$ March 2021;

Accepted:16 ${ }^{\text {th }}$ Aug. 2021

\begin{abstract}
Simultaneous spectrophotometric determination of captopril and hydrochlorothiazide in pharmaceutical formulations by the H-point standard addition method (HPSAM) is described. Absorbance at 211.5 and $230.3 \mathrm{~nm}$ was monitored upon the addition of standard solutions of captopril. The results showed that in prepared mixtures, captopril and hydrochlorothiazide can be determined simultaneously at concentration ratios varying from $1.0: 0.8$ to $2.5: 1.5 \mu \mathrm{g} / \mathrm{mL}$, respectively. Percentage recovery was found to be 95.33-104.37\% for captopril and $96.8-105 \%$ for hydrochlorothiazide, with a relative standard deviation (RSD) of $2.46 \%$. The method was successfully used to evaluate the antihypertensive captopril drug in a binary combination of hydrochlorothiazide in real samples with high precision and accuracy within the recovery percentage.
\end{abstract}

Keywords: H-point standard addition method, Captopril, Hydrochlorothiazide, Pharmaceutical formulations.

\section{Introduction}

Captopril (cap) is a pneumonia angiotensinconverting-enzyme inhibitor that reduces the risk of pneumonia by around one-third, compared with calcium channel or beta-adrenergic receptor antagonists, when used to treat hypertension in patients with a history of stroke ${ }^{[1]}$. Cap is an effective antihypertensive drug which is used both independently and in combination with other drugs (diuretics), such as hydrochlorothiazide (Hcz), to treat all types of hypertension and cardiac insufficiency ${ }^{[2]}$. Cap has the dissociation constants $\mathrm{pK}_{\mathrm{a} 1}=3.7$ (carboxyl group) and $\mathrm{pK}_{\mathrm{a} 2}=9.8$ (thiol group) ${ }^{[3]}$. Structurally, Cap is composed of four moieties: 1) pyrrolidine, 2) thiol group, 3) carboxyl group and 4) amide group, which are the most important parts for bioactivity and chemical activity of Cap, Figure 1.

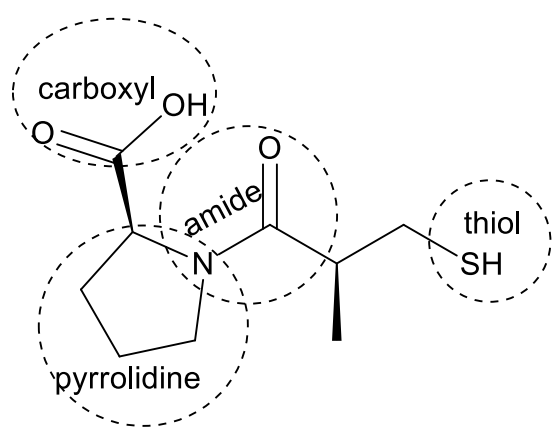

Figure 1. Chemical structure of cap.

Hcz is a thiazide of the diuretic type, used primarily to regulate elevated blood pressure as an antihypertensive agent. It is also used in 
combination with other drugs, where Hcz and another antihypertensive drug are applied in a single tablet to improve the effectiveness and reduce fluid accumulation. Hcz has the dissociation constants $\mathrm{pK}_{\mathrm{a} 1}=7.9$ and $\mathrm{pK}_{\mathrm{a} 2}=9.2^{[4,5]}$. Sructurally, Hcz is a benzothiadiazine, that is 3,4-dihydro-2H-1,2,4-benzothiadiazine 1,1-dioxide, substituted by a chloro group at position 6 and a sulfonamide at position 7 , as shown in Figure $2^{[6]}$.

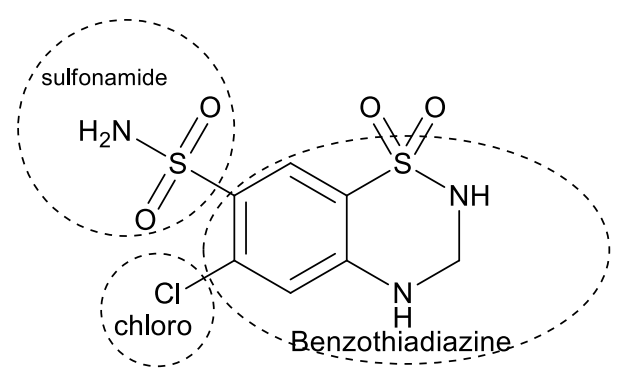

Figure 2. Chemical structure of $\mathrm{Hcz}$

Different methods have been used for the simultaneous determination of captopril and hydrochlorothiazide in combined dosage form. These include reverse-phase high performance liquid chromatography ${ }^{[7]}$, first derivative $(\mathrm{dA} / \mathrm{d} \lambda)$ and second derivative $\left(\mathrm{d}^{2} \mathrm{~A} / \mathrm{d} \lambda^{2}\right)$ UV-spectrophotometric methods and the application of zerocrossing technique of measurement, as well ${ }^{[8]}$. Combinations of captopril and hydrochlorothiazide in a ratio of $2: 1$ can be determined using the simultaneous equations resulting from the measurements of the maximum-to-minimum amplitudes of the first-order derivative spectrum D1 at $278-260 \mathrm{~nm}$ and at $213 \mathrm{~nm}^{[9]}$. In the multivariate spectral calibration methods, two linear regression-calibrations (bivariate calibration) and multi linear regression-calibrations have also been proposed ${ }^{[10]}$. A simple method of time-resolved chemiluminescence has been developed in which chemometrics and chemiluminescence measurements are combined with the aid of the stopped flow mixing technique ${ }^{[11]}$. A number of assay methods have been developed like voltammetric ${ }^{[12]}$, amperometric ${ }^{[13]}$ and high sensitive nanomaterial-based voltammetric sensor ${ }^{[14]}$. Several H-point standard addition methods (HPSAMs) for the simultaneous spectrophotometric determination of hydrochlorothiazide and furosemide ${ }^{[15]}$, hydrochlorothiazide and propranolol ${ }^{[16]}$, valsartan and hydrochlorothiazide ${ }^{[17]}$ have been developed. Since UV-visible spectrophotometry is a fast, sensitive and low-cost analytical method, which is appropriate to monitor the dosage of pharmaceutical preparations. In this work, the HPSAM was employed for the resolution of binary mixtures of cap and Hcz. The fundamental advantages of the HPSAM method currently under study are the simultaneous analysis of the components of the binary mixture without any chemical pretreatment, the short period of time necessary to do the measurement, low cost and the unnecessity of complex instrumentation. Moreover, the proposed method is based on a solid mathematical and statistical background. It avoids the use of highly toxic organic solvents that are widely used in chromatographic, electrometric and reagentbased colorimetric techniques. The simultaneous determination of Cap and Hcz using HPSAM depends on the selection of a suitable pair of wavelengths. The following principles have been applied to select the appropriate wavelengths. At the chosen wavelengths, (1) the analyte signals must be linear with concentration, (2) the interfering signal must remain constant with changes in the analyte concentration and (3) the analytical signal obtained from a mixture containing the analyte and the interference should be equal to the sum of the individual signals of the two species ${ }^{[18,19]}$. The method has been successfully applied for the direct estimation of the analytes studied in the pure mixtures as well as in pharmaceutical formulation. Good recoveries have been obtained, indicating the precision of the proposed method.

\section{Materials and Methods}

To prepare a $100 \mu \mathrm{g} / \mathrm{mL}$ cap stock solution or Hcz stock solution, $0.010 \mathrm{~g}$ of the drug (both provided by Awamedica Company for Drug Industries and Medical Applications Awa, Erbil Iraq) was dissolved in a sufficient amount of HPLC grade methanol (HGM) and diluted to 100 $\mathrm{mL}$ by HGM in a $100 \mathrm{~mL}$-volumetric flask. In order to investigate the interference effect, several species have been tested, including microcrystalline cellulose, stearic acid, starch, magnesium stearate and lactose, which are most commonly associated with captopril and hydrochlorothiazide in real samples. A stock solution of each interference species has been prepared and analyzed as suggested.

For the sample preparation of cap and $\mathrm{Hcz}$ in combination dosage form (pharmaceutical products captohexal 25:25 $\mathrm{mg}$ and captobeta 
25:12.5 mg cap and Hcz, respectively), ten tablets were accurately weighed and ground in a mortar to a fine powder. A quantity of the powder equivalent to one tablet was accurately weighed and dissolved in a sufficient amount of HGM in a beaker. The insoluble mass was filtered off through a filter paper (Whatman No. 41) and washed three times with $5 \mathrm{~mL}$-portions of HGM. The clear filtrate was transferred into a $50 \mathrm{~mL}$ volumetric flask and diluted up to the mark with HGM.

Several synthetic mixtures containing different concentration ratios of cap and $\mathrm{Hcz}$ (ranging between 4:1 and 1:3) were prepared in $10 \mathrm{~mL}$-volumetric flasks; standard additions of cap were made $(0-0.4 \mu \mathrm{g} / \mathrm{mL})$ and then, the flasks were filled to the mark with HGM. The solutions were left for $2 \mathrm{~min}$ at room temperature, after which $3.0 \mathrm{~mL}$ of the prepared solutions were transferred to a spectrophotometric quartz cell (path length of $1 \mathrm{~cm}$ ) and the absorbance was measured at 211.5 and $230.3 \mathrm{~nm}$ using a Perkin Elmer Lambda 25 double-beam UV-visible spectrophotometer (USA). The $\mathrm{H}$ point graphs were thus obtained. The concentration of cap $\left(\mathrm{C}_{\mathrm{H}}\right)$ was evaluated from the point of intersection of the two straight lines plotted for each H-point graph. The concentration ranges of cap and Hcz for the construction of HPSAM calibration graph were $0.8-4.0$ and $0.2-2.0$ $\mu \mathrm{g} / \mathrm{mL}$, respectively.

For the analysis of real samples, different volumes were taken from the drug stock sample solution and added into a $10 \mathrm{~mL}$-volumetric flask, followed by the addition of $(0-0.4) \mu \mathrm{g} / \mathrm{mL}$ of Cap. Then HGM was added up to the mark. Absorbance was measured at 211.5 and 230.3 nm.

\section{Results and discussion}

Several primary tests have been performed in order to determine the absorptivities of cap and $\mathrm{Hcz}$ in different solvents, aiming thereby at finding the solvent with maximum sensitivity and largest difference in the wavelength for maximum absorption by cap and $\mathrm{Hcz}\left(\lambda_{\max }\right)$. For this purpose, preparations of $10 \mu \mathrm{g} / \mathrm{mL}$ cap and $4.0 \mu \mathrm{g} / \mathrm{mL} \mathrm{Hcz}$ in various organic solvents, including analytical grade methanol, HGM, ethanol, water, acetone and acetonitrile, were tested in the wavelength range from $200 \mathrm{~nm}$ to $350 \mathrm{~nm}$ (Table 1, Figures 3 and 4). HGM shows, thereby, high absorption, good sensitivity and a satisfactory stability for the above described compounds. Although cap gives a higher absorption in ethanol, acetonitrile and water, higher stability could be found in HGM. In water and acetonitrile, cap gives incomplete absorption spectra in the UV region, while in ethanol, it showed a lower absorption stability than in HGM. In addition, analytical grade methanol gives lower absorption spectra than HGM, because the purity of HGM (99.9\%) is higher than that of analytical grade methanol $(96 \%)$, which increases the sensitivity of the spectra and gives higher absorption spectra than in analytical grade methanol. Hence, HGM was chosen as the best solvent for this analysis.

Table 1. Effect of solvents on cap and Hcz absorbance.

\begin{tabular}{|c|c|c|c|c|}
\hline \multirow[t]{2}{*}{ Solvents } & \multicolumn{2}{|c|}{ Cap $(10 \mu \mathrm{g} / \mathrm{mL})$} & \multicolumn{2}{|c|}{ Hcz ( $4 \mu \mathrm{g} / \mathrm{mL})$} \\
\hline & $\lambda_{\max }(\mathbf{n m})$ & Absorbance & $\lambda_{\max }(\mathbf{n m})$ & Absorbance \\
\hline \multirow{3}{*}{ Water } & \multirow{3}{*}{200} & \multirow{3}{*}{0.484} & 225.669 & 0.483 \\
\hline & & & 272.04 & 0.256 \\
\hline & & & 316.88 & 0.040 \\
\hline \multirow{3}{*}{ Ethanol } & \multirow{3}{*}{203.02} & \multirow{3}{*}{0.383} & 226.2 & 0.544 \\
\hline & & & 271.03 & 0.299 \\
\hline & & & 317.3 & 0.044 \\
\hline \multirow{3}{*}{ Analytical-grade Methanol } & \multirow{3}{*}{217.13} & \multirow{3}{*}{0.168} & 225.69 & 0.545 \\
\hline & & & 271.03 & 0.292 \\
\hline & & & 317.38 & 0.045 \\
\hline \multirow{3}{*}{ HGM } & \multirow{3}{*}{205.04} & \multirow{3}{*}{0.340} & 225.69 & 0.575 \\
\hline & & & 271.03 & 0.317 \\
\hline & & & 316.88 & 0.048 \\
\hline \multirow{3}{*}{ Acetonitrile } & \multirow{3}{*}{200.05} & \multirow{3}{*}{0.480} & 225.69 & 0.583 \\
\hline & & & 270.03 & 0.318 \\
\hline & & & 314.86 & 0.051 \\
\hline
\end{tabular}




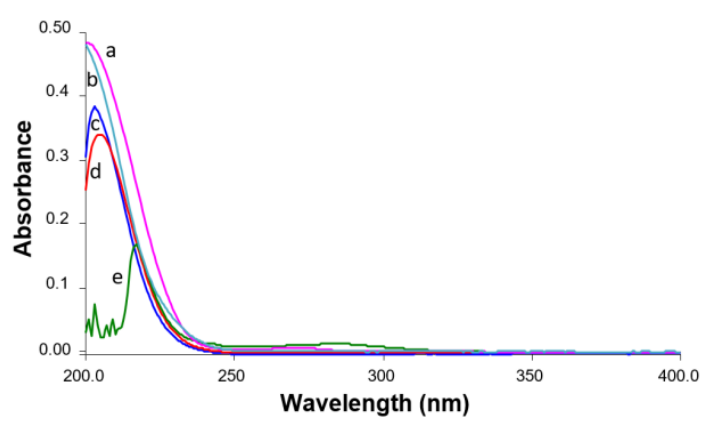

Figuer 3. Absorption spectrum of $10 \mu \mathrm{g} / \mathrm{mL}$ cap; a) acetonitrile, b) water, c) ethanol, d) HGM and e) analytical-grade methanol.

The absorption spectra of $4 \mu \mathrm{g} / \mathrm{mL} \mathrm{Hcz,} 10$ $\mu \mathrm{g} / \mathrm{mL}$ cap and a binary mixture of $\mathrm{Hcz}$ and cap were plotted against HGM as a blank in the range 200-400 $\mathrm{nm}$ (Figure 5). As can be seen, $\lambda_{\max }$ values for the two compounds are very close to each other and their spectra are strongly overlapping. It is therefore difficult to assess $\mathrm{Hcz}$ and cap in the presence of each other by classical spectrophotometry. For this reason, a chemometric method is needed to solve this problem and the HPSAM approach has been chosen to evaluate Cap and Hcz simultaneously.

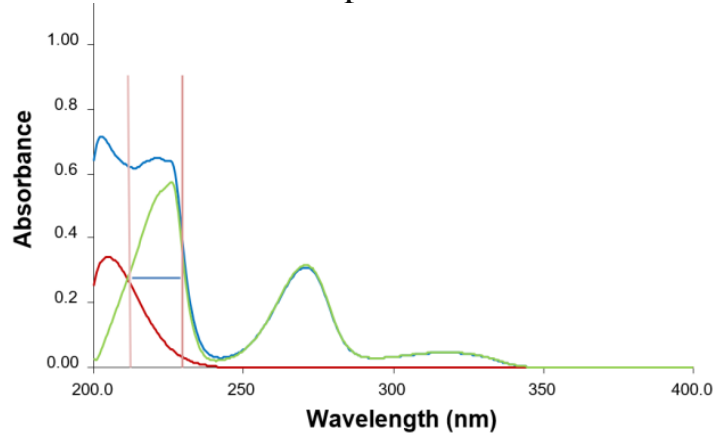

Figure 5. Absorption spectra of $4 \mu \mathrm{g} / \mathrm{mL}$ Hcz (gren), $10 \mu \mathrm{g} / \mathrm{mL}$ cap (red) and binary mixture (blue) in methanol.

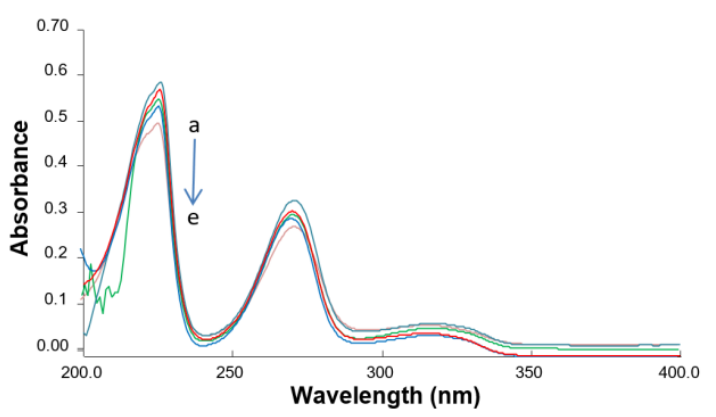

Figuer 4. Absorption spectrum of $4 \mu \mathrm{g} / \mathrm{mL}$ Hcz; a) acetonitrile, b) HGM, c) analyticalgrade methanol, d) ethanol and e) water.

In the current study, cap and Hcz can be considered as an analyte and interference, respectively. In this case and in view of the fact that the higher the slope value, the smaller the analyte concentration error, several pairs of wavelengths with the same Hcz absorbance were checked, Table 2. Known analyte quantities are successively added to the mixture (analyte and interference) and the resulting mixture absorbance was measured at the two selected wavelengths. The best pair was $211.5 \mathrm{~nm}$ and 230.3 $\mathrm{nm}$, as it gives the largest higher slope for the cap line and the greatest difference in the slope values of the standard addition curves $(0.0281$ at $211.5 \mathrm{~nm}$ and 0.0033 at $230.3 \mathrm{~nm}$ ), resulting in a cap recovery of $100 \%$; the intersection of the obtained two straight lines is the H-point $\left(-\mathrm{C}_{\mathrm{H}}\right.$, $\mathrm{A}_{\mathrm{H}}$ ) with $\mathrm{C}_{\mathrm{H}}$ being the analyte concentration and $\mathrm{A}_{\mathrm{H}}$ the analytical signal due to the interference. Figure 6 shows the HPSAM curves of cap as analyte and $\mathrm{Hcz}$ as interference at the two selected wavelengths. The $\mathrm{C}_{\mathrm{H}}$ concentration of cap was directly determined at the intersection of the $\mathrm{x}$-axis.

Table 2. Selection of correct wavelength for mixture analysis.

\begin{tabular}{|c|c|c|c|c|c|c|}
\hline \multirow{2}{*}{$\begin{array}{l}\text { Wavelength } \\
\quad(\mathbf{n m})\end{array}$} & \multirow[t]{2}{*}{ A-C Equation } & \multirow[t]{2}{*}{$\mathbf{R}^{2}$} & \multicolumn{2}{|c|}{$\begin{array}{l}\text { Amount taken } \\
\qquad(\mu \mathrm{g} / \mathrm{mL})\end{array}$} & \multirow{2}{*}{$\begin{array}{c}\begin{array}{c}\text { Amount } \\
\text { found } \\
(\mu \mathrm{g} / \mathrm{mL})\end{array} \\
\text { Cap }\end{array}$} & \multirow{2}{*}{$\begin{array}{c}\begin{array}{c}\text { Absorbance } \\
\left(\mathbf{A}_{\mathrm{H}}\right)\end{array} \\
\mathrm{Hcz}\end{array}$} \\
\hline & & & Cap & Hez & & \\
\hline 211.5 & $Y_{211.5}=0.0281 x+0.1376$ & 0.9911 & \multirow{2}{*}{3.0} & \multirow{2}{*}{1.0} & \multirow{2}{*}{3.0} & \multirow{2}{*}{0.0533} \\
\hline 230.3 & $Y_{230.3}=0.0033 x+0.0632$ & 0.9401 & & & & \\
\hline 218.6 & $Y_{218.6}=0.0154 x+0.1417$ & 0.9437 & \multirow{2}{*}{3.0} & \multirow{2}{*}{1.0} & \multirow{2}{*}{3.6} & \multirow{2}{*}{0.08175} \\
\hline 228.2 & $Y_{228.2}=0.0061 x+0.1055$ & 0.744 & & & & \\
\hline 213.6 & $Y_{213.6}=0.0241 x+0.1382$ & 0.9855 & \multirow{2}{*}{3.0} & \multirow{2}{*}{1.0} & \multirow{2}{*}{3.08} & \multirow{2}{*}{0.06392} \\
\hline 229.8 & $Y_{229.8}=0.0034 x+0.0744$ & 0.9561 & & & & \\
\hline
\end{tabular}




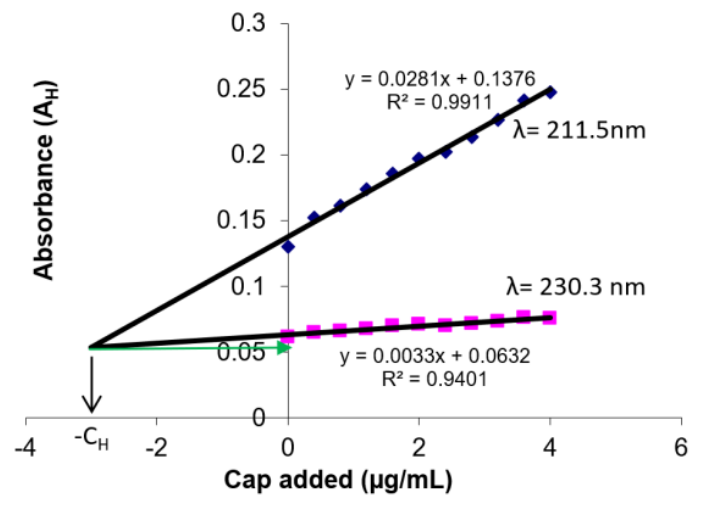

Figure 6. Plot for HPSAM curves at the selected wavelengths, $\lambda=211.5 \mathrm{~nm}$ and $\lambda=$ $230.3 \mathrm{~nm}$.

To determine the interference concentration from the ordinate value of the $\mathrm{H}$-point $\left(\mathrm{A}_{\mathrm{H}}\right)$, a calibration graph is required. Specific cap concentrations were added to different mixtures of constant cap concentration $(3 \mu \mathrm{g} / \mathrm{mL})$ and variable Hcz concentrations $(0-2.4 \mu \mathrm{g} / \mathrm{mL})$. The absorbance was measured at 211.5 and $230.3 \mathrm{~nm}$ and plotted against added cap concentrations, Figure 7. For the determination of Hcz interference concentration, a calibration curve is constructed by plotting the obtained $\mathrm{A}_{\mathrm{H}}$ values against the Hcz concentration, $(0-2.8 \mu \mathrm{g} / \mathrm{mL})$, Figure 8. Calibration within the concentration range of $0-2.4 \mu \mathrm{g} / \mathrm{mL}$ was found to be linear and there was a negative deviation above $2.4 \mu \mathrm{g} / \mathrm{mL}$, as shown in Figure 8. A good recovery of 97.33103.125 percent was achieved for Cap and $\mathrm{Hcz}$ in the mixture, Table 3.

In a similar way and for the determination of the analyte cap, specific cap concentrations were added to different mixtures of constant $\mathrm{Hcz}$ concentration $(1.0 \mu \mathrm{g} / \mathrm{mL})$ and variable cap concentrations $(0-4.0 \mu \mathrm{g} / \mathrm{mL})$. The absorbance was measured at 211.5 and $230.3 \mathrm{~nm}$ and plotted against added cap concentrations. The H-point $\left(-\mathrm{C}_{\mathrm{H}}, \mathrm{A}_{\mathrm{H}}\right)$ was determined as described above for Hcz. A calibration curve based on plotting obtained $\mathrm{C}_{\mathrm{H}}$ against the cap concentrations $(0$ 4.0 $\mu \mathrm{g} / \mathrm{mL}$ ) was then constructed for the determination of cap analyte concentration. The obtained calibration curve within the concentration range of $0-4.0 \mu \mathrm{g} / \mathrm{mL}$ was found to be linear and there was a negative deviation above 4.0 $\mu \mathrm{g} / \mathrm{mL}$. A good recovery of 96.04-104.70 percent was achieved for cap and Hcz in the mixture, Table 4.

To achieve the simultaneous determination of cap and Hcz in a sample, several synthetic

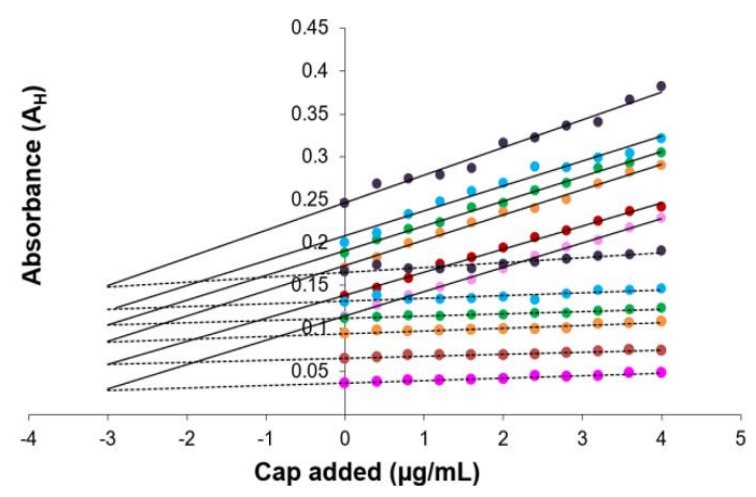

Figure 7. HPSAM curves for a fixed cap concentration $(3 \mu \mathrm{g} / \mathrm{mL})$ and different $\mathrm{Hcz}$ concentrations at $\lambda=211.5$ and $\lambda=230.3 \mathrm{~nm}$.

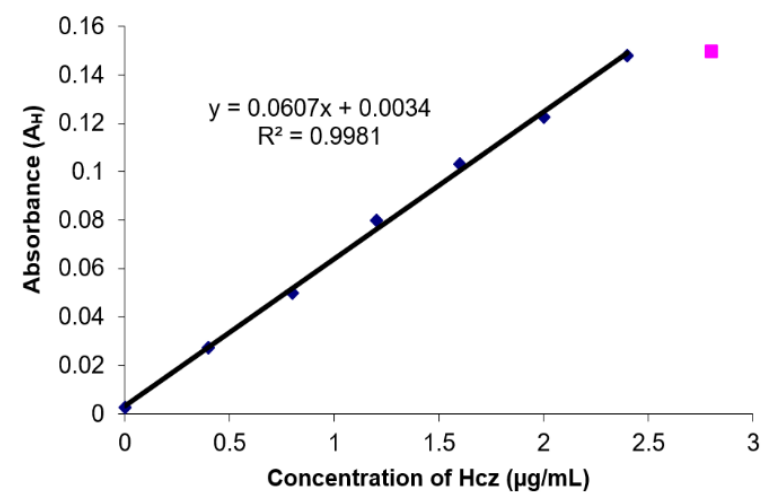

Figure 8. Calibration curve for $\mathrm{Hcz}$ in the presence of a fixed amount of cap $(3 \mu \mathrm{g} / \mathrm{mL})$.

mixtures with different concentration ratios of cap and Hcz were analyzed using HPSAM. As shown in Table 5, the accuracy of the results is satisfactory for cap-to-Hcz concentration ratios of $1.0: 0.8$ and 2.5:1.5. The results from the analysis of the different mixtures in the proposed method showed a range of 1.0-2.5 and 0.4-2.2 $\mu \mathrm{g} / \mathrm{mL}$ for cap and Hcz, respectively, Table 5 .

Accuracy was expressed as the relative recovery $(\%)$ and precision was expressed as the relative standard deviation (RSD\%). Three replication tests for the study of three different ratios of cap to $\mathrm{Hcz}$ mixtures have been conducted to test the accuracy and precision of the method, Table 6 . The relative recovery ranges for cap and Hcz using the current method were $99.6-103.96 \%$ and $95.88-103.91 \%$, respectively. In addition, the relative standard deviation range (RSD\%) for cap and Hcz were 0.52$2.31 \%$ and $0.69-2.46 \%$, respectively. The method's accuracy and precision met acceptability requirements. 
Table 3. Regression equations at $\lambda=211.5 \mathrm{~nm}$ and $\lambda=230.3 \mathrm{~nm}$ and recovery percentage for fixed cap and varied Hcz concentrations in the mixture.

\begin{tabular}{|c|c|c|c|c|c|c|c|}
\hline \multirow{2}{*}{ A-C Equation } & \multirow{2}{*}{$\mathbf{R}^{2}$} & \multicolumn{2}{|c|}{$\begin{array}{l}\text { Present } \\
(\mu \mathrm{g} / \mathrm{mL})\end{array}$} & \multicolumn{2}{|c|}{ Cap } & \multicolumn{2}{|c|}{ Hez } \\
\hline & & cap & Hez & $\begin{array}{l}\text { Found } \\
(\mu \mathrm{g} / \mathrm{mL})\end{array}$ & $\begin{array}{c}\text { Recovery } \\
(\%)\end{array}$ & $\begin{array}{l}\text { Found } \\
(\mu \mathrm{g} / \mathrm{mL})\end{array}$ & $\begin{array}{c}\text { Recovery } \\
(\%)\end{array}$ \\
\hline $\begin{array}{l}Y_{211.5}=0.0275 x+0.1091 \\
Y_{230.3}=0.0028 x+0.0343\end{array}$ & $\begin{array}{l}0.9816 \\
0.8517\end{array}$ & 3.0 & 0 & 3.028 & 100.93 & 0 & 0 \\
\hline $\begin{array}{l}Y_{211.5}=0.0284 x+0.1145 \\
Y_{230.3}=0.0029 x+0.0362\end{array}$ & $\begin{array}{c}0.9974 \\
0.966\end{array}$ & 3.0 & 0.4 & 3.07 & 102.33 & 0.393 & 98.25 \\
\hline $\begin{array}{l}Y_{211.5}=0.0274 x+0.1383 \\
Y_{230.3}=0.0033 x+0.0637\end{array}$ & $\begin{array}{l}0.9975 \\
0.9518\end{array}$ & 3.0 & 0.8 & 3.09 & 103.00 & 0.82 & 103.125 \\
\hline $\begin{array}{l}Y_{211.5}=0.0305 x+0.1704 \\
Y_{230.3}=0.0041 x+0.0907\end{array}$ & $\begin{array}{l}0.9931 \\
0.9444\end{array}$ & 3.0 & 1.2 & 3.01 & 100.33 & 1.23 & 102.50 \\
\hline $\begin{array}{l}Y_{211.5}=0.0289 x+0.1905 \\
Y_{230.3}=0.0027 x+0.1119\end{array}$ & $\begin{array}{l}0.9963 \\
0.9339\end{array}$ & 3.0 & 1.6 & 3.023 & 100.76 & 1.65 & 103.125 \\
\hline $\begin{array}{l}Y_{211.5}=0.0257 x+0.1978 \\
Y_{230.3}=0.0032 x+0.1319\end{array}$ & $\begin{array}{c}0.987 \\
0.6678\end{array}$ & 3.0 & 2.0 & 2.92 & 97.33 & 1.96 & 98.1 \\
\hline $\begin{array}{l}Y_{211.5}=0.0322 x+0.2463 \\
Y_{230.3}=0.0056 x+0.1657\end{array}$ & $\begin{array}{l}0.9761 \\
0.8736\end{array}$ & 3.0 & 2.4 & 3.041 & 101.36 & 2.39 & 99.58 \\
\hline
\end{tabular}

Table 4. Regression equations at $\lambda=211.5 \mathrm{~nm}$ and $\lambda=230.3 \mathrm{~nm}$ and recovery percentage for varied cap and fixed Hcz concentrations in the mixture.

\begin{tabular}{|c|c|c|c|c|c|c|c|}
\hline \multirow{2}{*}{ A-C Equation } & \multirow{2}{*}{$\mathbf{R}^{2}$} & \multicolumn{2}{|c|}{$\begin{array}{l}\text { Present } \\
(\mu \mathrm{g} / \mathrm{mL})\end{array}$} & \multicolumn{2}{|c|}{ Cap } & \multicolumn{2}{|c|}{ Hcz } \\
\hline & & Cap & Hez & $\begin{array}{l}\text { Found } \\
(\mu \mathrm{g} / \mathrm{mL})\end{array}$ & $\begin{array}{c}\text { Recovery } \\
(\%)\end{array}$ & $\begin{array}{l}\text { Found } \\
(\mu \mathrm{g} / \mathrm{mL})\end{array}$ & $\begin{array}{c}\text { Recovery } \\
(\%)\end{array}$ \\
\hline $\begin{array}{l}Y_{211.5}=0.0298 x+0.0857 \\
Y_{230.3}=0.0033 x+0.0762\end{array}$ & $\begin{array}{l}0.9822 \\
0.8855\end{array}$ & 0.8 & 1.0 & 0.803 & 100.37 & 0.96 & 96.04 \\
\hline $\begin{array}{l}Y_{211.5}=0.0288 x+0.1014 \\
Y_{230.3}=0.0028 x+0.0695\end{array}$ & $\begin{array}{l}0.9986 \\
0.9943\end{array}$ & 1.2 & 1.0 & 1.22 & 101.66 & 1.031 & 103.1 \\
\hline $\begin{array}{l}Y_{211.5}=0.0313 x+0.1184 \\
Y_{230.3}=0.0031 x+0.0718\end{array}$ & $\begin{array}{l}0.9961 \\
0.9686\end{array}$ & 1.6 & 1.0 & 1.65 & 103.12 & 1.030 & 103.10 \\
\hline $\begin{array}{l}Y_{211.5}=0.0272 x+0.1205 \\
Y_{230.3}=0.0029 x+0.0711\end{array}$ & $\begin{array}{c}0.992 \\
0.9802\end{array}$ & 2.0 & 1.0 & 2.04 & 102 & 1.014 & 101.40 \\
\hline $\begin{array}{l}Y_{211.5}=0.032 x+0.1463 \\
Y_{230.3}=0.0018 x+0.0722\end{array}$ & $\begin{array}{c}0.9933 \\
0.915\end{array}$ & 2.4 & 1.0 & 2.45 & 102.08 & 1.047 & 104.70 \\
\hline $\begin{array}{l}Y_{211.5}=0.0277 x+0.1463 \\
Y_{230.3}=0.003 x+0.0711\end{array}$ & $\begin{array}{l}0.9954 \\
0.9945 \\
\end{array}$ & 2.8 & 1.0 & 2.86 & 102.14 & 0.973 & 97.36 \\
\hline $\begin{array}{l}Y_{211.5}=0.0337 x+0.1725 \\
Y_{230.3}=0.0028 x+0.072\end{array}$ & $\begin{array}{l}0.9859 \\
0.9589\end{array}$ & 3.2 & 1.0 & 3.25 & 101.56 & 0.998 & 99.80 \\
\hline $\begin{array}{l}Y_{211.5}=0.0286 x+0.1692 \\
Y_{230.3}=0.0032 x+0.0755\end{array}$ & $\begin{array}{l}0.9948 \\
0.9051\end{array}$ & 3.6 & 1.0 & 3.688 & 98.33 & 0.9917 & 99.176 \\
\hline $\begin{array}{l}Y_{211.5}=0.0283 x+0.1761 \\
Y_{230.3}=0.0032 x+0.0756\end{array}$ & $\begin{array}{l}0.9961 \\
0.9773\end{array}$ & 4.0 & 1.0 & 4.0 & 100 & 0.976 & 97.69 \\
\hline
\end{tabular}


Table 5. Analysis of cap-Hez mixtures with different concentration ratios by HPSAM.

\begin{tabular}{|c|c|c|c|c|c|c|c|}
\hline \multirow{2}{*}{ A-C Equation } & \multirow{2}{*}{$\mathbf{R}^{2}$} & \multicolumn{2}{|c|}{$\begin{array}{l}\text { Present } \\
(\mu \mathrm{g} / \mathrm{mL})\end{array}$} & \multicolumn{2}{|c|}{ Cap } & \multicolumn{2}{|c|}{ Hez } \\
\hline & & Cap & Hez & $\begin{array}{l}\text { Found } \\
\mu \mathrm{g} / \mathrm{mL})\end{array}$ & $\begin{array}{c}\text { Recovery } \\
(\%)\end{array}$ & $\begin{array}{c}\text { Found } \\
\mu g / m L)\end{array}$ & $\begin{array}{c}\text { Recovery } \\
(\%)\end{array}$ \\
\hline $\begin{array}{l}Y_{211.5}=0.0258 x+0.0639 \\
Y_{230.3}=0.0016 x+0.0362\end{array}$ & $\begin{array}{l}0.988 \\
0.8891 \\
\end{array}$ & 1.2 & 0.5 & 1.144 & 95.33 & 0.509 & 101.8 \\
\hline $\begin{array}{l}Y_{211.5}=0.0353 x+0.0871 \\
Y_{230.3}=0.0036 x+0.0341\end{array}$ & $\begin{array}{l}0.9953 \\
0.8545 \\
\end{array}$ & 1.6 & 0.4 & 1.67 & 104.37 & 0.405 & 101.25 \\
\hline $\begin{array}{l}Y_{211.5}=0.0409 x+0.0871 \\
Y_{230.3}=0.0036 x+0.1567\end{array}$ & $\begin{array}{l}0.9934 \\
0.903 \\
\end{array}$ & 1.8 & 2.2 & 1.84 & 102.22 & 2.31 & 105 \\
\hline $\begin{array}{l}Y_{211.5}=0.0381 x+0.090 \\
Y_{230.3}=0.0072 x+0.0589\end{array}$ & $\begin{array}{l}0.9966 \\
0.9576\end{array}$ & 1.0 & 0.8 & 1.01 & 101 & 0.784 & 98 \\
\hline $\begin{array}{l}Y_{211.5}=0.0311 x+0.1743 \\
Y_{230.3}=0.0026 x+0.1025\end{array}$ & $\begin{array}{l}0.985 \\
0.9125 \\
\end{array}$ & 2.5 & 1.5 & 2.519 & 100.76 & 1.523 & 101.53 \\
\hline $\begin{array}{l}Y_{211.5}=0.025 x+0.112 \\
Y_{230.3}=0.0026 x+0.0674\end{array}$ & $\begin{array}{l}0.9776 \\
0.9867\end{array}$ & 2.0 & 1.0 & 1.99 & 99.5 & 0.968 & 96.8 \\
\hline
\end{tabular}

Table 6: Accuracy and precision for the HPSAM determination of Hcz and cap in mixture.

\begin{tabular}{|c|c|c|c|c|c|c|c|c|c|}
\hline \multirow[t]{2}{*}{ A-C Equation } & \multirow[t]{2}{*}{$\mathbf{R}^{2}$} & \multicolumn{2}{|c|}{$\begin{array}{l}\text { Present } \\
(\mu \mathrm{g} / \mathrm{mL})\end{array}$} & \multicolumn{2}{|c|}{$\begin{array}{l}\text { Found } \\
(\mu \mathrm{g} / \mathrm{mL})\end{array}$} & \multicolumn{2}{|c|}{$\begin{array}{c}\text { Recovery } \\
(\%)\end{array}$} & \multicolumn{2}{|c|}{$\begin{array}{c}\text { RSD* } \\
(\%)\end{array}$} \\
\hline & & Cap & Hez & Cap & Hez & Cap & Hcz & Cap & Hez \\
\hline $\begin{array}{l}Y_{211.5}=0.0315 x+0.1185 \\
Y_{230.3}=0.0029 x+0.0721\end{array}$ & $\begin{array}{l}0.9976 \\
0.9962 \\
\end{array}$ & 1.6 & 1.0 & 1.62 & 1.05 & 102.0 & 99.1 & \multirow{3}{*}{0.51} & \multirow{3}{*}{2.46} \\
\hline $\begin{array}{l}Y_{211.5}=0.0309 x+0.1166 \\
Y_{230.3}=0.0031 x+0.0718\end{array}$ & $\begin{array}{l}0.9903 \\
0.9686 \\
\end{array}$ & 1.6 & 1.0 & 1.61 & 1.04 & 101.0 & 97.9 & & \\
\hline $\begin{array}{l}Y_{211.5}=0.0305 x+0.114 \\
Y_{230.3}=0.0031 x+0.0694\end{array}$ & $\begin{array}{l}0.9917 \\
0.9695\end{array}$ & 1.6 & 1.0 & 1.62 & 1.00 & 101.0 & 96.8 & & \\
\hline $\begin{array}{l}Y_{211.5}=0.0301 x+0.0835 \\
Y_{230.3}=0.0032 x+0.0642\end{array}$ & $\begin{array}{l}0.9985 \\
0.9935\end{array}$ & 0.8 & 1.0 & 0.81 & 0.96 & 100.8 & 95.9 & \multirow{3}{*}{0.83} & \multirow{3}{*}{2.02} \\
\hline $\begin{array}{l}Y_{211.5}=0.0296 x+0.0881 \\
Y_{230.3}=0.0027 x+0.0661\end{array}$ & $\begin{array}{l}0.9958 \\
0.9940\end{array}$ & 0.8 & 1.0 & 0.82 & 0.99 & 102.2 & 99.5 & & \\
\hline $\begin{array}{l}Y_{211.5}=0.0292 x+0.0871 \\
Y_{230.3}=0.0029 x+0.0659\end{array}$ & $\begin{array}{l}0.9983 \\
0.9811\end{array}$ & 0.8 & 1.0 & 0.81 & 0.99 & 100.8 & 99.1 & & \\
\hline $\begin{array}{l}Y_{211.5}=0.0305 x+0.1704 \\
Y_{230.3}=0.0041 x+0.0907\end{array}$ & $\begin{array}{l}0.9931 \\
0.9444\end{array}$ & 3.0 & 1.2 & 3.01 & 1.23 & 100.3 & 102.5 & \multirow{3}{*}{2.31} & \multirow{3}{*}{0.69} \\
\hline $\begin{array}{l}Y_{211.5}=0.0299 x+0.1720 \\
Y_{230.3}=0.0040 x+0.0912\end{array}$ & $\begin{array}{l}0.9901 \\
0.9509 \\
\end{array}$ & 3.0 & 1.2 & 3.11 & 1.24 & 104.0 & 103.3 & & \\
\hline $\begin{array}{l}Y_{211.5}=0.0305 x+0.1704 \\
Y_{230.3}=0.0040 x+0.0911\end{array}$ & $\begin{array}{l}0.9884 \\
0.9499\end{array}$ & 3.0 & 1.2 & 2.98 & 1.25 & 99.6 & 103.9 & & \\
\hline
\end{tabular}


The effect of some common excipients, such as cellulose-microcrystalline, magnesium stearate, starch stearic acid and lactose monohydrate, was studied by analyzing synthetic mixture solutions $(1.0 \mu \mathrm{g} / \mathrm{mL}$ of $\mathrm{Hcz}$ and 3 $\mu \mathrm{g} / \mathrm{mL}$ of cap) with excess amounts $(50 \mu \mathrm{g} / \mathrm{mL}$ and $100 \mu \mathrm{g} / \mathrm{mL}$ ) of each excipient separately. The percentage recovery was calculated using the general HPSAM described above. Table 7 indicates that the excipients did not interfere with the determination of cap and Hcz.

In order to evaluate the analytical applicability of the current method, it was applied to the simultaneous determination of cap and $\mathrm{Hcz}$ in tablets. The results are listed in Table 8 . The good agreement between the findings and the composition values suggested by the suppliers indicates that HPSAM is effectively applicable to the simultaneous evaluation of cap and $\mathrm{Hcz}$ in pharmaceutical formulations.

The current method was compared with three previously reported spectrophotometric methods based on chemometric approaches (Table 9$)^{[20]}$. When comparing the methods, it was found that the current method could detect low concentrations of cap and Hcz, making it more suitable for the determination of cap and Hcz in biological samples.

Table 7: Effect of excipients on the simultaneous determination of cap and Hcz by HPSAM.

\begin{tabular}{lcccc}
\hline \multirow{2}{*}{ Excipients } & \multicolumn{2}{c}{$\mathbf{5 0} \boldsymbol{\mu g} / \mathbf{m L}$ excipient } & \multicolumn{2}{c}{$\mathbf{1 0 0} \boldsymbol{\mu g} / \mathbf{m L}$ excipient } \\
& Recovery\% & Error\% & Recovery\% & Error\% \\
\hline Cellulose-microcrystalline & 100.8 & -0.8 & 105.7 & -5.3 \\
Magnesium stearate & 102.3 & -2.3 & 103.3 & -3.3 \\
Starch & 102 & -2 & 99.9 & 0.1 \\
Stearic acid & 103 & -3 & 102.5 & -2.1 \\
lactose monohydrate & 100.9 & -0.9 & 102.1 & -2.1 \\
\hline
\end{tabular}

Table 8. Determination of cap and Hcz in pharmaceutical products by HPSAM.

\begin{tabular}{|c|c|c|c|c|c|c|c|c|}
\hline \multirow{2}{*}{$\begin{array}{l}\text { Pharmaceutical } \\
\text { Formulation }\end{array}$} & \multirow{2}{*}{ A-C Equation } & \multirow{2}{*}{$\mathbf{R}^{2}$} & \multicolumn{2}{|c|}{$\begin{array}{c}\text { Taken } \\
(\mu \mathrm{g} / \mathrm{mL})\end{array}$} & \multicolumn{2}{|c|}{$\begin{array}{c}\text { Found } \\
(\mu \mathrm{g} / \mathrm{mL})\end{array}$} & \multicolumn{2}{|c|}{$\begin{array}{c}\text { Recovery } \\
(\%)\end{array}$} \\
\hline & & & Cap & Hez & Cap & Hez & Cap & Hez \\
\hline Captobeta & $\begin{array}{l}Y_{211.5}=0.0259 x+0.1133 \\
Y_{230.3}=0.0027 x+0.0674\end{array}$ & $\begin{array}{l}0.9946 \\
0.9911\end{array}$ & 2.0 & 1.0 & 1.98 & 0.97 & 98.92 & 96.62 \\
\hline Captobeta & $\begin{array}{l}Y_{211.5}=0.0259 x+0.0638 \\
Y_{230.3}=0.001 x+0.037\end{array}$ & $\begin{array}{l}0.9963 \\
0.9896\end{array}$ & 1.0 & 0.5 & 1.08 & 0.54 & 107.63 & 107.14 \\
\hline Captohexal & $\begin{array}{l}Y_{211.5}=0.0423 x+0.2136 \\
Y_{230.3}=0.0096 x+0.1464\end{array}$ & $\begin{array}{l}0.9941 \\
0.9223 \\
\end{array}$ & 2 & 2 & 2.06 & 2.03 & 102.75 & 101.54 \\
\hline Captohexal & $\begin{array}{l}Y_{211.5}=0.0389 x+0.1027 \\
Y_{230.3}=0.0056 x+0.0681\end{array}$ & $\begin{array}{l}0.9939 \\
0.9573\end{array}$ & 1.0 & 1.0 & 1.03 & 0.97 & 103.09 & 97.00 \\
\hline
\end{tabular}

Table 9: Comparison of the HPSAM developed in this study with literature reports of spectrophotometric methods based on chemometric approaches.

\begin{tabular}{|c|c|c|c|c|}
\hline Method & HPSAM & $\begin{array}{l}\text { Simultanous } \\
\text { equation }{ }^{[20]}\end{array}$ & Q-analysis method & $\begin{array}{l}\text { First derivative } \\
\text { method }^{[20]}\end{array}$ \\
\hline$\lambda_{\max }, \mathrm{nm}$ & $\begin{array}{l}211.5 \mathrm{~nm} \mathrm{Cap} \\
230.3 \mathrm{~nm} \mathrm{Hcz}\end{array}$ & $\begin{array}{l}205 \text { nm Cap, } \\
271 \mathrm{~nm} \mathrm{Hcz}\end{array}$ & $\begin{array}{l}209 \text { nm Cap } \\
271 \mathrm{~nm} \mathrm{Hcz}\end{array}$ & $\begin{array}{l}222 \mathrm{~nm} \text { Cap } \\
340 \mathrm{~nm} \mathrm{Hcz}\end{array}$ \\
\hline $\begin{array}{l}\text { Linear range, } \\
\mu \mathrm{g} / \mathrm{mL}\end{array}$ & $\begin{array}{l}0.8-4.0 \text { Cap } \\
0.4-2.4 \mathrm{Hcz}\end{array}$ & $\begin{array}{l}\text { 5-35 } \mu \mathrm{g} / \mathrm{mL} \\
\text { Cap, Hcz }\end{array}$ & $\begin{array}{c}10-120 \\
\mu \mathrm{g} / \mathrm{mL} \text { Cap, } \mathrm{Hcz}\end{array}$ & $\begin{array}{l}1-30 \text { Cap } \\
1-40 \mathrm{Hcz}\end{array}$ \\
\hline $\begin{array}{l}\text { Correlation } \\
\text { Coefficient, } \mathbf{R}^{2}\end{array}$ & $\begin{array}{c}0.9907 \text { Cap, } 0.9981 \\
\text { Hcz }\end{array}$ & 1 Cap, $0.9996 \mathrm{Hcz}$ & $\begin{array}{l}0.9962 \text { Cap, } \\
0.9999 \mathrm{Hcz}\end{array}$ & 0.999 Cap, Hcz \\
\hline Solvent & HGM & $\begin{array}{c}\text { Methanol \& distilled } \\
\text { water }\end{array}$ & $\begin{array}{c}\text { Methanol \& distilled } \\
\text { water }\end{array}$ & $\begin{array}{c}\text { Methanol \& distilled } \\
\text { water }\end{array}$ \\
\hline Application & Tablet & Tablet & Tablet & Tablet \\
\hline
\end{tabular}




\section{Conclusion}

It was observed that cap and Hcz in their mixtures show overlapping absorption spectra. Therefore, the simultaneous spectrophotometric determination of cap and $\mathrm{Hcz}$ in their synthetic and commercial tablets was performed using the HPSAM. The proposed method does not require prior separation steps and/or spectral derivation. The suggested method provides the advantages of being economic, highly sensitive and selective. In addition, it avoids the use of highly toxic organic solvents which are widely used in the case of chromatographic, electrometric and reagent-based colorimetric methods. The method was successfully used for the direct estimation of cap and Hcz in pure mixtures and pharmaceutical formulations, where good recovery values were obtained, indicating the accuracy of the proposed method.

\section{References}

[1] Bylund, D., Captopril: Reference Module in Biomedical Sciences, Elsevier 2017, pp. 1-7.

[2] Vardanyan, R.; Hruby, V., Synthesis of essential drugs, Elsevier, 2006.

[3] Karaffa, L. S., The Merck Index: An Encyclopedia of Chemicals, Drugs and Biologicals, RSC Publishing, 2013.

[4] Williams, D. A.; Lemke, T. L., pKa Values for Some Drugs and Miscellaneous Organic Acids and Bases, In: Foye's Principles of Medicinal Chemistry, BaltimorePhiladelphia: Lippincott Williams \& Wilkins, 2002, pp.1070-1080.

[5] IARC Monographs on the Evaluation of Carcinogenic Risks to Humans: List of Classifications, Volumes 1-116, International Agency for Research on Cancer (IARC), Lyon, France, 2016, 108.

[6] Sweetman, S. C., Martindale: The Complete Drug Reference, Pharmaceutical Press, 2009.

[7] Kirschbaum, J.; Perlman, S., J. Pharm. Sci., 1984, 73, 686-687.

[8] Panderi I.; Parissi-Poulou. M., Intern. J. Pharm., 1992, 86, 99-106.

[9] Salem, H.; El-Maamli, M.; El-Sadek, M.; Kheir, A., Spectrosc. Lett., 1991, 24, 451470.
[10] Ustündağ O.; Dinç, E., Pharmazie, 2003, $58,623-628$.

[11] Yao, H.C. ; Sun, M.; Yang, X. F.; Zhang, Z. Z.; Li, H., J. Pharm. Anal., 2011, 1, 32-38.

[12] Gholivand, M. B.; Khodadadian, M., Electroanalysis, 2013, 25, 1263-1270.

[13] Gimenes, D. T.; Marra, M. C.; de Freitas, J. M.; Muñoz, R. A. A.; Richter, E. M., Sens. Actuators, B, 2015, 212, 411-418.

[14] Karimi-Maleh, H.; Ganjali, M. R.; Norouzi, P.; Bananezhad, A., Mater. Sci. Eng., 2017, 73, 472-477.

[15] Hajian, R.; Shams, N.; Zarifmanesh, A., Asian J. Chem., 2011, 23, 1344-1348.

[16] Hajian, R.; Shams, N.; Rad, A. , J. Braz. Chem. Soc., 2009, 20, 860-865.

[17] Lakshmi, $\quad$ K.; Lakshmi, $\quad$ S., $\quad$ Acta Pharm., 2011, 61, 37-50.

[18] Falcó, P. C.; Reig, F. B.; Benet, A. M., Fresenius' J. Anal. Chem., 1990, 338,1621.

[19] Al-Sabha, T. N.; Bunaciu, A. A; AboulEnein, H. Y., App. Spectrosc. Rev., 2011, 46, 607-623.

[20] Rao, K. S.; Panda, M.; Keshar, N. K., Chron. Young Sci., 2012, 3, 37-41. 